\title{
A NEW INTERPRETATION OF THE STRUCTURE OF INTERNAL HELLENIDES
}

\author{
Argyriadis I. ${ }^{1}$, Midoun M. ${ }^{2}$ and Ntontos P. ${ }^{3}$ \\ ${ }^{1}$ Cabinet de Géologie Argyriadis, 975 chemin du Pré de Caune, 83740 La Cadière d'Azur, France \\ E-Mail:ion@argyriadis.net \\ ${ }^{2}$ Cabinet 2 M Conseils, Le Condorcet 18 rue Elie Pelias13016 Marseille \\ E-Mail: geode2m@gmail.com \\ 34 G. Griva st., 21100,Nafplio - Greece E-Mail: ntontos@naf.forthnet.gr
}

\begin{abstract}
This study is based on some new observations made from Southern and Central Evia, Argolis and North-central part of Pindos. Our observations lead us to adopt a simplified view of the paleogeography of Greek mainland just before the Alpine orogeny. The subsequent varied tectonic units originate mainly from the following paleogeographic areas:

- A carbonate Arab-African shelf margin which displays several lateral transitions, ridges and basins. In the Greek mainland this margin is represented by the Preapulian, Ionian, GavrovoTripolis, Parnassos zones, Olympus platform and probably the Kavala and Thassos Marbles.

- A transition zone from the shelf units to the Tethys ophiolites (Pindos Zone, Styra, Argolis and Hydra, Eretrias new unit).

- Tethys ophiolites, which might represent an "ocean" fault zone or subduction of lithosphere along a weak zone.

- An Hercynian continental mass (Servomacedonian).
\end{abstract}

\section{Introduction}

New field observations made from Southern (IA) and Central Evia (IA and MM), Argolis (IA and PN) and North-central part of Pindos (IA). The combination of them, leads us to adopt a new aspect of the structure of internal Hellenides. Starting with a briefly description for each area we will pass through the conclusions to the new aspect.

In southern Evia three main tectonic units are exposed, the Almyropotamos unit, Tsakaioi-Ochi unit and Styra unit while in the northern part of the island, we distinguished a new unit consisting of Seta's Paleozoic and Dirfis-Olympus (Eretrias) Mesozoic limestones. This complex is underlying the ophiolitic complex of Central Euboia separated by a thick mylonitic zone.

In the Argolis area, three main units are present: Mesozoic limestones at the bottom, a mylonitized zone consisting of ophiolitic and chert matrix including limestone remnants in the middle and the ophiolitic complex of Eastern Greece at the top of succession.

In northern and central Pindos area, we describe the existence of Late Cretaceous (Campanian) transgressions over ophiolitic bodies indicating the presence of Pindos Zone east of Parnassos Zone, near the ophiolitic complex of Eastern Greece. 


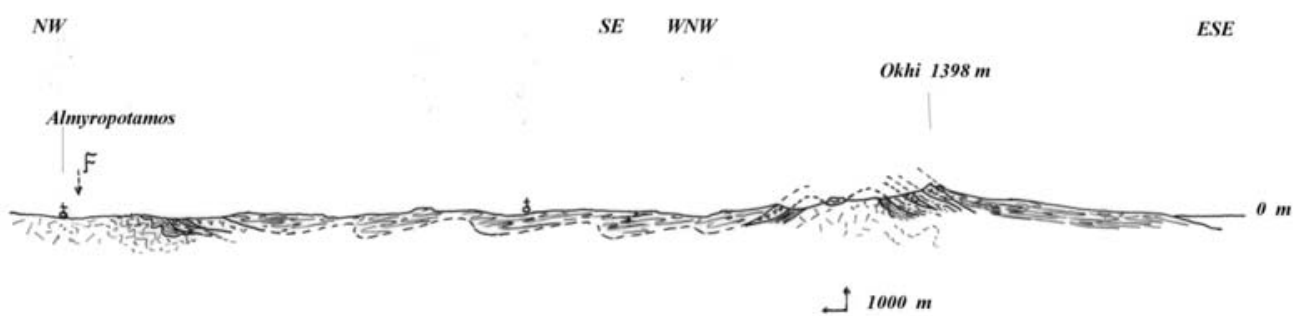

Fig. 1: Geological section of South Evia (I. Argyriadis, 2005).

\section{Evia}

Evia belongs to the internal Hellenides and for many years many scientists argue for the geological composition. We will consider the south part first and then the central part.

\subsection{Southern Evia}

Southern Evia constitutes part of Attica-Cyclades massif; a stack of metamorphic formations, which their age and the structure, has been an argument issue since the dues of $19^{\text {th }}$ century. Since 1967 an announcement was made (Argyriadis 1967), according to which Southern Evia is a tectonic window, underlying the units of Central Evia and Northern Attica. This interpretation assumes four (4) units:

- Almyropotamos unit consisting of Mesozoic marbles.

- Tsakaioi unit consisting of schist and amphibolite including large bodies of serpentine.

- Styra unit consisting of thin plate marble, sipoline, quartzite and amphibolitic schist.

- Ochi unit is consists of glaucophane schist, large bodies of amphibolite and manganese microquartzite.

Since then, many researchers (Argyriadis et al 1976, Aubouin 1977, Dubois \& Bignot 1979, Gerneut 1971, Katsikatsos 1971, 1977, 1991, Katsikatsos et al 1986, Lensky et al 1997, Maluski et al 1981, Papanikolaou 1987, Shaked et al 2000) adopt that subdivision fulfilling and refining the details: Paleocene's metaflysch over Almyropotamo's marbles, "blue schists" over the other units, adopting also new nomenclature (see Geological Map of IGME). However, this first subdivision contained "errors of youth" that are retracted by the newer observations of the author and thus today, the dominate aspect is that exists only three units which are multiple folded: the Almyropotamos unit at the bottom and the other two units, Styra and Tsakaioi-Ochi, at the top of succession. Depending the later folding the upper unit change. For example, at the site Rouklia-Lala, Styra unit is overthrusted marbles which form an anticline while a thin ophiolitic intercalation exists. Furthermore Styra unit is overthrust over the ophiolitic assemblage of Ochi unit from Platanisto to the Ochi shelter.

\subsection{Central Evia}

Central Evia is considered as a sedimentary succession consisting by Paleozoic slates and limestone, Mesozoic limestone of Triassic and Jurassic period bearing ophiolites. This succession is «sealed» by transgressive Cenomanian limestone followed by thin bedded Late Campanian limestone where they progressively pass to flysch (Maastrichtian to Paleocene) (Argyriadis 1966, Aubuin 1977 , Aubuin et al 1976, Deprat 1904, Guernet 1971, Renz 1940). 


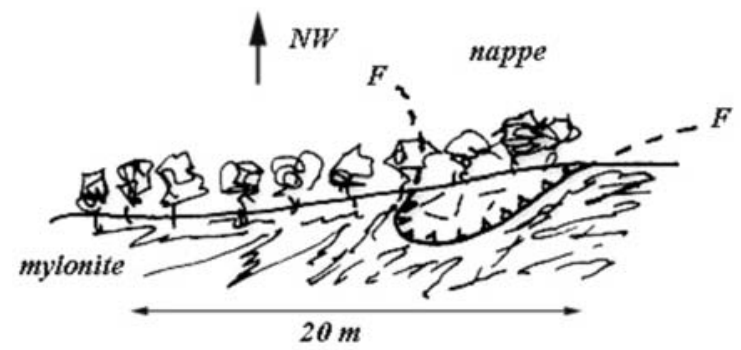

Fig. 2: The contact between Central Evia's unit and mylonite. Position's coordinates $38^{\circ}$ $25^{\prime} 54^{\prime \prime} \mathrm{N}$ and $23^{\circ} 42^{\prime} 30^{\prime \prime} \mathrm{E}$.

Our researches in the region led us to distinguish a new unit. The fossiliferous Mesozoic limestone of Dirfis-Olympus unit is placed tectonically below the Paleozoic Seta's unit although the contact between the two units seems to be a stratigraphic conformity. This conformity can be seen on the section of the road from Eretria to Geronta. In other words the whole system seems to be reversed.

The lineaments that differentiate the new unit from the so far called Central Evia's unit are:

- The unit is intensely folded. The plunge direction of the main fold axes are $90^{\circ}$ to $100^{\circ}, 45^{\circ}$ and $300^{\circ}$.

- The folds whose main axis trends to E-W are mainly isoclinals, upright or inclined to NNE while those whose main axis trends to NW-SE are inclined to SW (Dinaric folds).

- The Paleozoic component of the unit is constituted by clastic sediments containing intercalations of limestone. Triassic begins with volcanic rocks and tuffs while Jurassic and probably Early Cretaceous turns to cherts, quartzites and thin plate limestones (J. Deprat in 1904 found Early Cretaceous fossils SW of Dirfi's mountain and M. Lys had mention "ghosts" of Early Cretaceous foraminifera).

- There seems to be no emersion, unconformity or transgression except local "hard ground" of Late Paleozoic

There is tectonic relationship between the new unit and Central Evia's unit with the last one being over the first one. The overthrust plane, folded after the thrust movement, is characterized by the presence of a remarkable broad mylonite, frequently many hundreds meters thick. The new unit is surrounded by that mylonite:

- Westwards, is present from Malakonta surrounding the folded west side of Olympus Mountain (with remnants of gabbros, pillow lavas, radiolarite, which can be seen from Ag. Anna's church near Geronta), covered by newer sediments until Kambia where there is a remarkable zone of fragmented dolomite. The mylonite continues around Dirfi, Steni, Ag. Athanasios, Glyfada (Tserges) to the Aegean Sea. It has to be noticed that the new unit is reversed and that is obvious at Liri (East side of Dirfi's cone) and at Tsougaraki col on the road from Ag. Athanasio to Glyfada, where we can see Paleozoic slates above the Mesozoic limestones.

- From north-eastern the mylonite arises in the land in Metoxi in order to turns to Manikia and Paramerites (tectonic remnants and mylonite of ophiolites) heading towards Aliveri.

- In the southern, the mylonite is present in Oropos region as the last formation towards the sea.

We underline that the new unit includes the mountain range from Dirfi to Xerovouni and Skotini which is constituted by limestone. This limestone pass under Seta's slates and reappears in Olympus region.

It is therefore a unit (paleogeographic area) with many of its constitutive formations been known but 
they were consider to be part of Central Evia's ophiolites. Furthermore, remarkable mylonite has not been mentioned before, considering being "schists-chert" formation. We believe that this unit is a completely different paleogeographic area than ophiolitic complex of Eastern Greece which is present northern of Chalkida city. We will call this new unit as Eretria's unit.

\section{Argolis}

Geological maps of this area suffer from a confusion presenting an extended Late Cretaceous flysch formation of "sediments of passage from Eastern Greece zone to Pindos zone" (Bachmann \& Risch 1978, Bannert \& Bender 1968, Baumgartner 1985, Clift 1996, Dercourt 1970, Leibundgut et Attinger 1986, Renz 1940). Actually, there are limited occurrences of flysch formation. However the majority of occurrences are a formation that we will refer to as "mélange". It is a thick mylonite zone with intense deformation that includes radiolarite, remnants of serpentine, blocks of limestone usually of Late Cretaceous period and mainly clastic sediments with ophiolite origin. This clastic material is characterized by the presence of roundstones which are strongly orientated and cleaved. Here are some examples:

- In Tolo city, geological map presents flysch formation placed tectonically over Late Cretaceous limestone or under Triassic limestone. Actually, mylonite is overthrust recrystallized limestone probably of Triassic age. This can be seen on the road towards Tolo's port. This mass includes blocks of underlying limestone, sandstones with ophiolite origin, fragmented radiolarite and pillow lavas and blocks of black limestone. Moving north-westwards to the waste bank of Tolo, at the col of Seitan-bachtse site we see the tectonic contact between the mylonite and subjacent limestone. Limestone is karstified before upthrust and ophiolitic material seems to be depressed inside karstic cavities. The same mylonite can be seen under the ancient castle of Asini.

- In the area of Pyrgiotika village, flysch formation exists but it is under the mylonite with the contact between these two formations being intensely folded. Easternly of the village we observe remnant of serpentine inside the mylonite, covered by white and purple calcschists with Globotruncana sp.. Nearby there is a tectonic remnant of white limestone and radiolarite always inside the mylonite.

- In the area of Marathea village, peaks of Goumouria and Aetovigla are chisel out in thick bedded limestone in the base of which Lower Triasic lavas exists. Despite what geological map describe, this limestone is not over the flysch formation but below it. Even more this formation is not flysch but mylonite which is overthrust onto the Triassic limestone. This overthrust can be seen clearly near the Ag. Georgios's church which is founded on limestone tectonic remnants inside the mylonite.

- In Argos city, Aspida's hill consists of highly altered ophiolite with transgressive bioclastic limestone, probably of Late Cretaceous epoch. Flysch is totally absent and Larrisa's hill consists of radiolarite and thin plate, pink, limestone of Pindos Zone, covered by thick bedded limestones, probably Cretaceous (near Panagias's Monastery).

- Westwards of Argos City in the area of Ag. Triada's church there is an extended appearance of highly altered ophiolite which contains old, pedogenetic surfaces covered by lateritic crusts and angeritic dolomites continental or lacustrine origin. On that surface seems to lie in stratigraphic conformity limestone with hornstone intercalations containing ostracodes.

- In site Akova, limestone of the eastern front of Loutses Mountain is below tectonically fragmented ophiolite which in turn is below intensely folded sandstone with ophiolitic origin. 
$W$

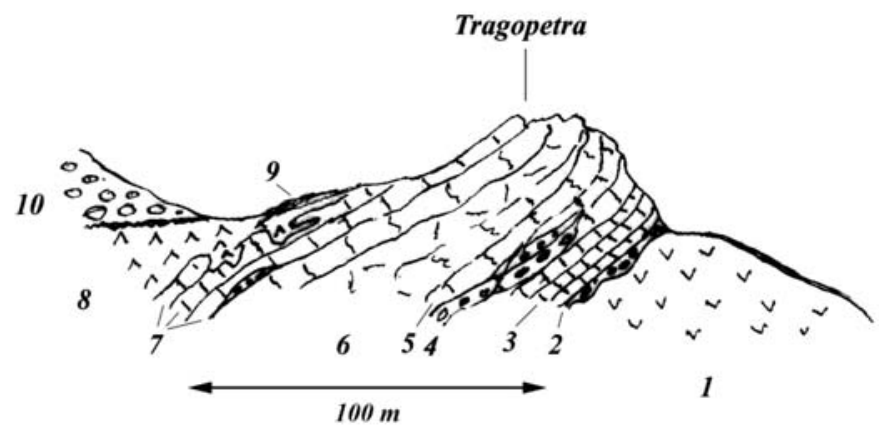

Fig. 3: Tragopetra's geological section (see text for explanation).

Constructively in Argolis area, three paleogeographic areas are present: a carbonate shelf belonging to Paleo-African margin, a continental slope (Pindos Zone) which now forms tectonic slices and the ophiolitic complex of Eastern Greece tectonically placed at the top of succession. The original fingerprint of this research is the recognition of the broad mylonite just like Evia.

\section{Pindos}

\subsection{Northern Pindos}

A Late Cretaceous transgression over ophiolitic complex has been described (Argyriadis 2004, 2007). In this region, ophiolitic complex has been tectonically placed over Pindos Zone (Philippson 1890, Reinhardt 1911, Kober 1931, 1952, Renz 1940, Brunn 1956). Inside ophiolitic complex there are limestones of Triassic, Jurassic age, or Upper Cretaceous, even Eocene epoch, embedded or intercalated. An array of limestone outcrops is observed eastern of Katara site. From south to north we meet Tragopetra, Petra Portas, anonymous outcrops and Megali Petra. Common attribute between these outcrops is the Late Cretaceous epoch. Although Brunn (1956), primary, had interpreted these outcrops as tectonically placed, today it has been proved (Argyriadis 2004) that they are transgression's remnants.

The most reachable outcrop is Tragopetra, beside the National Road 6, about 2 km eastern of Katara's col. Here, the origin of ophiolite is peridotite and gabbros which fluctuates to doleritic lavas. It is fully serpentinized and has strong tectonic deformation. The columnar section of the specific site is (microfauna determinations by G. Tronchetti, Marseille):

- Ophiolitic lavas at the bottom (1).

- Transgressive conglomerate (2) consisting of ophiolitic rounded shingles mainly peridotite and gabbros and sometimes radiolarite. Conglomerate fulfils concavities on ophiolite's surface. Thickness range from 10 to $100 \mathrm{~cm}$.

- Thin layer (about $10 \mathrm{~cm}$ thick) of red coloured limestone.

- White coloured bedded limestone (3) up to 7-8 m thick. At the bottom they contain ophiolitic pebbles same as the previous ones. In the last two calcareous horizons founded Globotruncana linneiana, Gl. bulloïdes, Gl. arca, Contusotruncana fornicata, as well as Rugoglobigerina sp., Heterohelix striata, Pseudotextularia sp., Plassoglobulina sp., Calcisphaerulidae showing Late Campanian age. 


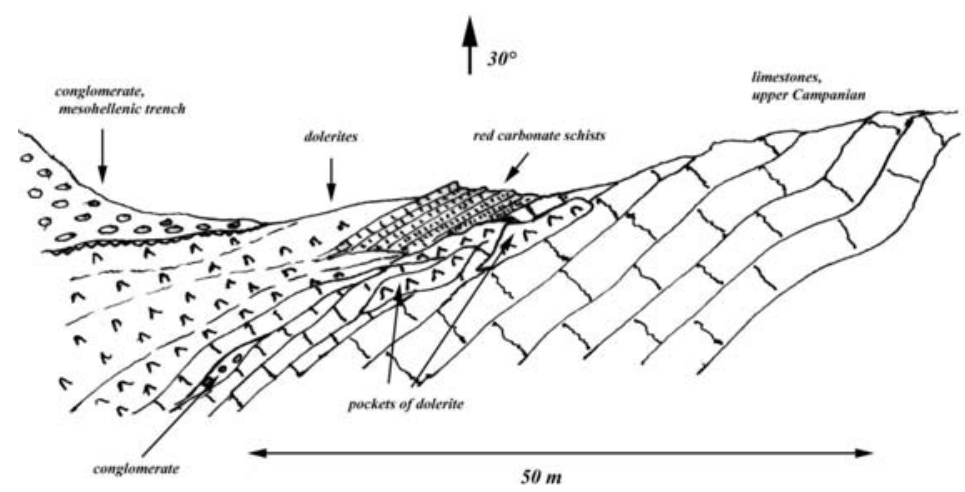

Fig. 4: Detailed view of Tragopetra's limestone outcrop.

- Miscellaneous conglomerate (4) up to 1-2 m thick, containing ophiolitic, quartzite, crystallic rock and limestone pebbles.

- Pink coloured limestone (5), up to 2-3 m thick, with cleavages and lenticular intercalations of conglomerate. It has the same microfauna with layer (3).

- White coloured thick bedded limestone (6) up to $30 \mathrm{~m}$ thick. Only small orbicular foraminifera have been founded without key fossils.

- Pink coloured, thin bedded limestone (7), up to few meters thick, with lenticular intercalations of conglomerate same as previous. It has the same Globotruncana microfossils but even more, Globotruncanella havanensis, showing Early Maastrichtian age. The limestone series ends upwards in a karstic surface with big concavities.

- Effusions of doleritic lavas (8), completely different than previous one of ophiolite, also fully alterated. Locally lava penetrates and discharges inside the concavities of subjacent karst. The thickness is estimated to $50 \mathrm{~m}$.

- Superimposed red carbonate schists (9), fulfilling the concavities of subjacent doleritic lavas, up to $1-2$ m thick.

- Conglomerate (10), of Auversian age over previous lava formation, in stratigraphic conformity. It is also miscellaneous but different than previous one, consisting of big boulders (up to $20 \mathrm{~cm}$ diameter) of crystallic rock. It is the base of MesoHellenic Trench.

About a kilometre north of Tragopetra, in site "Tzina" an array of outcrops begins trending north. The first outcrop is called "Petra Portas" and constitutes of transgressive limestone with Globotruncana, up to $20 \mathrm{~m}$ thick, over peridotite. The limestone fluctuates to red coloured, cleavage limestone and then to altered doleritic lavas. A fingerprint of "Petra Portas" is the active karst big enough to supply a spring.

Northernly thus Tzina's col, we can observe other three similar outcrops with reducing thickness of limestone. In the outcrop which is 200 m easternly of the col, above the limestone instead of doleritic lavas there is a series of red, green and white radiolarite, up to $5 \mathrm{~m}$ thick. Upwards this series discontinues by tectonic contacts with superjacent ophiolite.

The northern and last outcrop, Megali Petra, is the thickest outcrop of limestone, more than $50 \mathrm{~m}$ thick. It is intensively folded, with main axis trending N-S and E-W. Some of them have an intense vertical component. The whole structure forms a rock mass extending for many hundreds meters. The columnar section of the specific site is (microfauna determinations by G. Tronchetti, Marseille): 


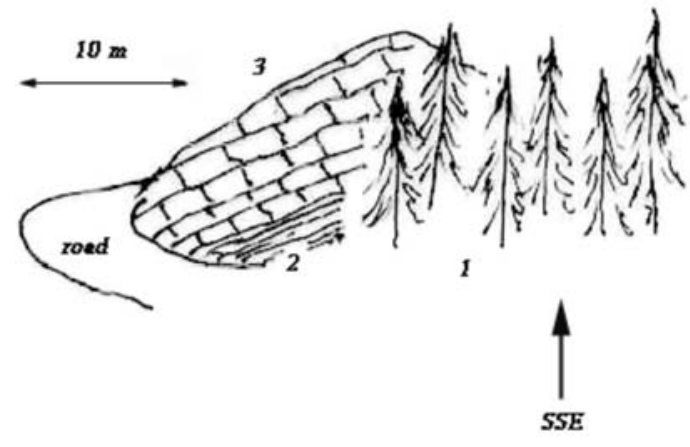

Fig. 5: Outcrop of serpentine in "Melana Litharia". 1: serpentine, 2: pink calcschists, 3: transgressive limestone of Campanian.
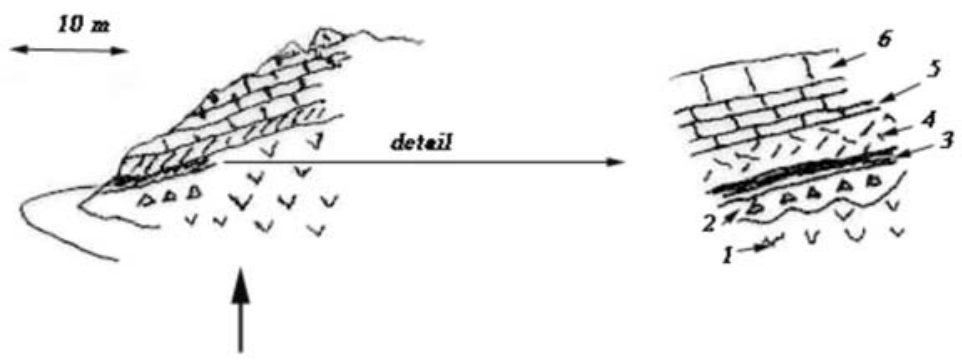

Fig. 6: Outcrop of serpentine in "Melana Litharia" $300 \mathrm{~m}$ southernly from previous outcrop. 1: serpentine, 2: breccias up to $20 \mathrm{~cm}$ thick, with limestone and ophiolite fragments, 3: Crust up to $5 \mathrm{~cm}$ thick of altered volcanic matrix 4: Altered volcanic rock up to $1 \mathrm{~m}$ thick, 5: thin plate limestone with Globotruncana arca, 6: white limestone with Gl. Arca and Gl.cf calcarata.

- High altered peridotite (serpentine) at the bottom.

- Coarse-grain arkose of varying thickness (fulfils concavities of subjacent surface).

- Thin bedded, purple coloured limestone, up to $5 \mathrm{~m}$ thick. There are signs of intense thermal influence while intrusions of altered lava are present. Many non determinable shells of elasmobranches have been found.

- Red, cleavage limestone, up to 5-6 m thick.

- Thin bedded, white or pink coloured limestone, up to $20 \mathrm{~m}$ thick, with Globotruncana fossils just like Tragopetra's outcrop and conglomerates intercalations with boulders and pebbles of peridotite, lavas, radiolarite in a calcareous matrix. In the upper horizons of this formation Globotruncanita cf. Calcarata has been founded showing Upper Campagnian age.

- Succession of sandstone and clastic limestone at the bottom and authentic red radiorarite and plate limestone with Globotruncana upwards.

\subsection{Central Pindos}

Something similar can be observed at Vardousia Mountain, in the area of Artotina, about $6 \mathrm{~km}$ south of the village. In Arenta Mountain (1604 m), in a site, called "Melana Litharia“, a serpentinized ophiolitic mass covered northwards by transgressive limestone with Globotruncana, is tectonically placed between flysch formations. 
This ophiolitic mass is constituted of serpentines, gabbros, pillow lavas, radiolarite, etc. Transgressive limestone, up to $25 \mathrm{~m}$ thick, becomes upwards thin bedded, pink coloured ending up as pinkviolet calcschists. This formation is intensively deformed and is under and simultaneously over flysch formation. It is just the case of tectonic insertion defined up and down by tectonic unconformities. The subjacent flysch formation contains clastic material of ophiolitic origin indicate that Pindos Zone and Tethys ophiolites was in direct adjacency. We remind that in Parnassos unit the carbonic sedimentation goes up to Eocene and flysch begins afterwards (Renz 1940, Aubuin 1977).

\section{Conclusions}

According to Ch. Lyell's principle of "actualism" we can conclude for each studied area:

- In South Evia, the lower unit (Almyropotamos) is considering to be a carbonate shelf-margin. This unit is identified as part of the Paleo-African - Arab shelf margin. Styra unit, identified as part of the continental slope from the shelf units to the Tethys ophiolites is overthrust Almyropotamos unit. The contact between the two units is strongly multi-phase folded. At least one folding phase is younger than main thrust movement, trapping Tethys's ophiolite which had to be over Styra unit.

- In Central Evia, we describe the Eretria unit identified as part of the same continental slope, also strongly folded with isoclinal or inclined folds but significant less extent of metamorphism. Above Eretria unit we find overthrust Central Evia's unit consisting of ophiolites, transgressive limestone of Late Cretaceous and flysch. This overthrust is characterized by the strong folding of contact's surface and the existence of a broad mylonite.

- In Argolis, except the minimal metamorphism (or the lack of it) we have the same situation: a carbonate shelf at the bottom and over that, fragmented, discontinuous wedges of a paleogeographic continental slope (Pindos Zone and relative transition sediments). At the top we find overthrust an ophiolitic complex (SubPelagonian Zone).

- In Pindos, our observations answer a question of the classic conception for internal Hellenides: the existence, Easternly from Pindos Zone, Parnassos Zone, namely an insertion of carbonic shelf between Pindos continental slope and Tethys's ophiolites. In Northern Pindos, we have the evidence that ophiolites were deformed and repeatedly had emerged and corroded before the Campagnian (transgression of Late Jurassic in Vermio, Middle Cretaceous westwards from Vourino and Campagnian in the region of Metsovo) and that also the Dinaric thrust movements before Auversian became in sculptural conditions and in no case in depths of subduction zone. In Southern Pindos, the existence of ophiolite wedges - or even olistholites - inside flysch of Late Cretaceous-Paleocene shows obviously that the period before the trust movements of Late Eocene, Pindos continental slope was next Tethys's ophiolites, Easternly of Parnassos shelf, and the overthrust of Parnassos on Pindos became in later phase.

Synthetic interpretation. Our observations lead us to adopt a simplified view of the paleogeography of Greek mainland just before the Alpine orogeny. The subsequent varied tectonic units originate mainly from the following paleogeographic areas:

- A carbonate Arab-African shelf margin which displays several lateral transitions, ridges and basins. In the Greek mainland this margin is represented by the Preapulian, Ionian, GavrovoTripolis, Parnassos zones, Olympus platform and probably the Kavala and Thassos Marbles (Argyriadis \& Fourquin, 1987).

- A transition zone (continental slope) from the shelf units to the Tethys ophiolites (Pindos Zone, Styra, Argolis and Hydra, Eretrias new unit. 
- Tethys ophiolites, which might represent an "ocean" fault zone or subduction of lithosphere along a weak zone.

- An Hercynian continental mass (Servomacedonian).

Already in Middle Cretaceous or even earlier, Tethys's ophiolite was deformed and at least folded but also was emerged (see laterites, transgressions and disagreements of Middle and Late Cretaceous, etc). This emersion possibly characterizes and certain parts of African shelf. Immediately afterwards ophiolites overthrust on the African shelf in an enormous movement, which drifted, fragment and disintegrated the continental slope, like Pindos. This movement is accompanied also by proportional locomotion of European-Asian mass. It is deformed in the scale of planet. It is obvious that this major movement was followed by a phase of compaction and strongly, isoclinal folding, trending from SSW to NNE (see Southern and Central Evia). Most obvious today (because newest) deformation during Late Eocene and Oligocene are relatively more limited and rather of minor importance if we examine the total area of deformation that is extended from Caribbean to Indonesia.

\section{References}

Argyriadis I. 1966. La série stratigraphique de l'Eubée moyenne (Grèce). Existence de mouvements intrasénoniens. C. R. Acad. Sci., Paris, 262 (D), p. 2427 - 2430.

Argyriadis I. 1966. Sur la tectonique de l'Eubée moyenne. Présence de lambeaux allochtones et raccord probable avec la Macédoine. C.R. Acad. Sci., Paris, 262 (D), p. 2577-2580.

Argyriadis I. 1967. Sur le problème des relations structurales entre formations métamorphiques et non métamorphiques en Attique et en Eubée. C.R. Acad.Sci., Paris, 264 (D), p. 438-441.

Argyriadis I. 1975. Mésogée permienne, chaîne hercynienne et cassure téthysienne. Bull. Soc. Géol.Fr., (7), p. 56-67.

Argyriadis I. 2000. La tectonique de la Basse Provence: proposition d'une interprétation nouvelle. C.R. Acad. Sc. Paris, IIa, vol. 331 n²12, p. $797-802$.

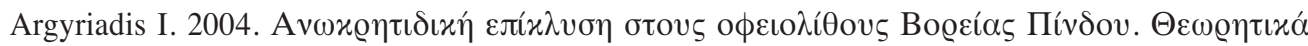
б $\mu \pi \varepsilon \varrho \alpha ́ \sigma \mu \alpha \tau \alpha$ (Upper cretaceous transgression over the ophiolites of northern Pindos). Bull. Geol. Soc. Greece vol. XXXVI, 2, 2004, p. 802 - 807.

Argyriadis I. \& Fourquin Cl. 1987. La structure du complexe de nappes rhodopien en Grèce: une fenêtre hellénique africaine sous les Balkans. C.R. Acad.Sci.Paris, 305, Série II, p. 727-732.

Argyriadis I., Mercier J.L., Vergely P., 1976. La fenêtre d'Attique-Cyclades et les corrélations Hellénides -Taurides. C.R. Acad.Sci., Paris, 283, (D), p. 599-601.

Argyriadis I., 1974. Sur l'orogenèse mésogéenne des temps crétacés. Revue de Géogr. Phys. et Géol. Dyn., vol. XVI, 1, p. 23 - 60.

Argyriadis I., Graciansky P.C. (de), Marcoux J., Ricou L.E., 1980. The opening of the Mesozoïc Tethys between Eurasia and Arabia-Africa. 26e CGI, Coll. 5, Eds BRGM, p. 199-214.

Aronis G., 1964. Observations on the coastal karst of Greece. Mémoires A.I.H., t. V, Réunion d'Athènes 1962 , p. $256-265$.

Aubouin J., 1977. Méditerranée orientale et Méditerranée occidentale: esquisse d'une comparaison du cadre alpin. Bull. Soc. Géol. Fr., (7), XIX, n³, p. 421-435.

Aubouin J., Bonneau M., Davidson J., Leboulenger P. et Matesco S. 1976. Esquisse structurale de l'arc égéen externe: des Dinarides aux Taurides. Bull. Soc. Géol. Fr., (7), XVIII, p. 327-336.

Bachmann, G. and Risch, H., 1978. Late Mesozoic and Paleogene development of the Argolis peninsula 
(Peloponesos). In: Closs, H., Roeder, D. and Schmidt, K., (eds). Alps, Apennines and Hellenides. Schweiserbart, Stuttgart, pp. 424-427.

Bannert, D. and Bender, H., 1968. Zur Geologie der Argolis-Halbinsel (Peloponnes, Griechenland). Geologica et Palaeontologica, 2, 151-162.

Baumgartner, P., 1985. Jurassic sedimentary evolution and nappe emplacement in the Argolis peninsula (Peloponessus, Greece). Memoire de la Societie Helvetique pour la Science Naturelle.

Bonzanigo, L., 1982. Géologie de l'arrière pays d"Erétrie (Eubée, Grèce). Travail de Diplôme à l'Ecole Polytechnique Fédérale, Zürich.

Brunn, J.H., 1952. Les éruptions ophiolitiques dans le NW de la Grèce et leurs rapports avec l'oro genèse. 19 ème congrès géol. Int.17, 19-27.

Brunn, J.H., 1956. Contribution à l'étude géologique du Pinde septentrional et de la Macédoine occidentale. Ann. Géol. Pays Hellen. 7, 410 p.

Brunn, J.H., 1960. Mise en place et différenciation de l'association pluto-volcanique du cortège ophiolitique. Rev. Géogr. phys. Géol. dyn., Sér. 2, 3, 115-132.

Brunn J.H., Argyriadis I. and Braud J. 2001. Magmatic emplacement of northwestern Greece ophiolites. Proccedings of the 9th International Congress of the Geological Society of Greece, 2001, Bull. Geol. Soc. Greece, XXIV, vol. 6.

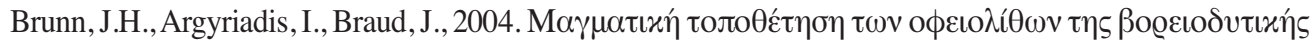
E $\lambda \lambda \alpha \alpha_{\delta} \alpha \varsigma$ (Magmatic emplacement of northwestern Greece ophiolites.). Bull. Geol. Soc. Greece, XXXVI, 4, 2004, p. 1625 - 1628.

Celet, P. et Ferrière, J., 1978. Les Hellénides internes: le Pélagonien. Eclogae Geol. Helvetiae 71/3, 467 - 495.

Clift, P. and Robertson, A., 1990. Deep-water basins within the Mesozoic carbonate platform of Argolis, Greece. Journal of the Geological Society, 147, 825-836.

Clift, P., 1992. The collision tectonics of the southern Greek Neotethys. Geologische Rundschau, 81/3, 669-679.

Clift, P., 1996. Accretion tectonics of the Neotethyan Ermioni Complex, Peloponessos, Greece. Journal of the Geological Society, 153, 745-757.

Degnan, P.J., Robertson, A.H.F, 1991. Tectonic and sedimentary evolution of the Western Pindos Ocean: NW Peloponnese, Greece. Bull. Geol. Soc. Greece, 25/1, 263-273.

Degnan, P.J., Robertson, A.H.F., 1998. Mesozoic-early Tertiary passive margin evolution of the Pindos ocean (NW Peloponnese, Greece). Sedimentary Geology, 117, 33-70.

Deprat, J., 1903. Sur la structure de l'île d'Eubée. C.R. Acad. Sci., Paris, 137, 666 - 668.

Deprat, J., 1903. Notes préliminaires sur la géologie de l'île d'Eubée. B.S.G.F., (4), 3, 229 - 243 et B.S.G.F. (7), 4, 340 - 356.

Deprat, J., 1904. Etude géologique et pétrographique de l'île d'Eubée. Thèse, Besançon 1904. Carte géol.

Dercourt, J., 1970. L'expansion océanique actuelle et fossile: ses implications géotectoniques. Bull. Soc. Géol.Fr., (7), 12, 261-317.

Dubois, R. and Bignot, G., 1979. Présence d'un "hard ground" nummulitique au-delà de la série crétacée d'Almyropotamos (Eubée méridionale, Grèce). C.R. Acad.Sci., Paris, 289, 993-995.

Gautier, P. and Brun, J.P., 1994. Crustal-scale geometry and kinematics of late-orogenic extension in the central Aegean (Cyclades and Evvia Island). Tectonophysics, 238, 399-424.

Guernet, Cl., 1971. Etudes géologiques en Eubée et dans les régions voisines (Grèce). Thèse, Paris 1971, $395,50 \mathrm{pl}$.

Jones, G., Robertson, A., Cann, J., 1990. Genesis and emplacement of the supra-subduction zone Pindos 
ophiolite, northwestern Greece. In: Tj. Peters et al., eds., Ophiolite genesis and evolution of the oceanic lithosphere. Ministry of Petroleum and Minerals, Oman, 771-799.

Katsikatsos, G., 1991a. Geological map of Greece, Aliveri sheet. I.G.M.E., Athens, Greece.

Katsikatsos, G., 1991b. Geological map of Greece, Rafina sheet. I.G.M.E., Athens, Greece.

Katsikatsos, G., Migiros, G., Triantaphyllis, M., Mettos, A., 1986. Geological structure of internal Hellenides (E. Thessaly, SW Macedonia, Euboea, Attica, Northern Cyclades islands and Lesvos). I.G.M.E. Geological and Geographical Research, special issue, $191-212$.

Katsikatsos, G., 1971. L'âge du système métamorphique de l'Eubée méridionale et sa subdivision stratigraphique. Prak. Acad. Athènes, 44, 223-238.

Katsikatsos, G., 1977. La structure tectonique d'Attique et de l'île d'Eubée. Réun. Extraord. Soc. Géol. Fr.et de Grèce en Grèce, 1976, Bull. Soc. Géol. Fr., (7), XIX, 1, 75-80.

Kober, L., 1915. Alpen und Dinariden. Geol. Rudsch. 5, 175-204, Leipzig 1915.

Kober, L., 1931. Das alpine Europa. Borntraeger, Berlin.

Kober, L., 1952. Leitlinien der Tektonik Jugoslaviens. Serbische Akad. D. Wiss. Sonderausgabe, 189, Geol. Institut, n. 3.

Koumantakis, J., Matarangas, D., 1980. Geological map of Greece, Panayia sheet.

Laubscher, H.P., Bernoulli, D., 1977. Mediterranean and Tethys. In: Nairn et al. Eds., The Ocean basins and margins. IV, Mediterranean Plenum Publ., New York.Jackson E., Green H., Moores E., 1980. The Vourinos ophiolite, Greece: cyclic units of lineated cumulates overlying harzburgite tectonite. Geol. Soc. Amer. Bull., 86, 390-398.

Leibundgut, Ch. et Attinger, R., 1986. Coastal Region between Argos and Astros. In Karst hydrogeology of central and eastern Peloponnesus (Greece). Morphis M. and Zojer H. Eds.

Lekkas, S. and Lozios, S. 2000. Tectonic structure of Mt. Hymittos. Ann. Géol. Pays Helléniques., 38, C, $47-62$.

Lensky, N., Avigad, D., Garfunkel, Z., Evans, B.W., 1997. The tectono-metamorphic evolution of blueschists in South Evia, Hellenide Orogenic belt (Greece). Israel Geological Society, Annual Meeting 1997, 66-67.

Lepsius, R., 1893. Geologie von Attika. Ein Betrag zur Lehre vom Metamorphismus der Gesteine; Berlin $1893,592 \mathrm{p}$.

Maluski, H., Vergely, P., Bavay, D., Bavay, P., Katsikatsos, G., 1981. 39Ar/40Ar dating of glaucophanes and phengites in southern Euboea (Greece) ; geodynamic implications. Bull. Soc. Géol. Fr., 5, 469-476.

Mavridis, A., Skoyrtsis-Koroneou, V., Tsaila-Monopoli St., 1977. Contribution to the geology of the subPelagonian zone (Vourinos area, West-Macedonia). VI coll. Aegean Region, Athens 1977, v. I, 175-195.

Mercier, J., 1968. Etude géologique des zones internes des Hellénides en Macédoine centrale (Grèce). Ann. Géol. Pays Helléniques, 20, 596 p.

Moores, E.M., 1969. Petrology and structure of the Vourinos ophiolite complex of Nothern Greece. Geol. Soc. Amer., Spec. Paper, 118, 74 p.

Papanikolaou, D.J., 1984. The three metamorphic belts of the Hellenides: a review and a kinematic interpretation. In The Geological evolution of the Eastern Mediterranean (eds J.E. Dixon and A.H.F. Robertson), 551-560. Geological Society of London, special publication $\mathrm{n}^{\circ} 17$.

Papanikolaou, D.J., 1986. Late Cretaceous paleogeography of the metamorphic Hellenides. I.G.M.E. Geological \& Geographical Research, special issue, 315-328.

Papanikolaou, D.J., 1987. Tectonic evolution of the Cycladic blueschist belt (Aegean Sea, Greece). In Chemical Transport in Metasomatic Processes (ed. H.C. Helgeson) 429-450. NATO ASI series, 218c. 
Parrot, J.F., 1977. Ophiolites du Nord-Ouest syrien et évolution de la croûte océanique téthysienne au cours du mésozoïque. Tectonophysics, 41, 251-268.

Philippson, A., 1890. Bericht über eine Reise durch Nord- und Mittel-Griechenland. Zeitschr. D. Ges. F. Erdk. 25, 331-416.

Piper, D.J.W., Pe-Piper, G., 1980. Was there a western (external) source of terrigenous sediment for the Pindos zone of the Peloponnese (Greece)?. Neues Jahrbuch für Geologie und Paläontologie, Monatshefte 1980, 107-115.

Reinhardt, M., 1911. Sur l'existence de la nappe des roches ophiolitiques en Macédoine. C.R. de Séances de l'Institut géologique de Roumanie, Bucarest, 19.

Renz, C., 1940. Die Tektonik der griechischen Gebirge. Mém. Acad. Ath. 8, 1-171.

Renz, C. et Reichel, M., 1945. Beiträge zur Stratigraphie und Paläontologie des ostmediterranen Jungpaläozoïkums und dessen Einordnungim Griechischen Gebirgssystem. I und II Teil: Geologie und Stratigraphie. Eclogae Geol. Helvetiae 36, Nr 2 (1945), 211 - 313, mit 3 Textfig. und 1 Tafel 'IX).

Ricou, L.E., 1971. Le croissant ophiolitique péri-arabe, une ceinture de nappes mises en place au Crétacé supérieur. Rev. Géogr. Phys. Géol.dyn. (2), vol. XIII, 4, 327-350.

Ricou, L.E., Argyriadis, I., Marcoux, J., 1975. L'axe calcaire du Taurus, un aligne,ent de fenêtres araboafricaines des nappes radiolaritiques, ophiolitiques et, éta,orphiques. Bull. Soc. Géol.Fr., (7), XVII, $1975, n^{\circ} 6,1024-1044$.

Robertson, A.H.F., Clift, P.D., Degnan, P.J., Jones, G., 1991. Palaeogeographic and palaeotectonic evolution of the Eastern Mediterranean Neotethys. Palaeogeography, Palaeoclimatology, Palaeoecology, 87, 289-343.

Seidel, E., Kreuzer, H., Harre, W., 1982. A late Oligocene/early Miocene high pressure belt in the external Hellenides. Geologisches Jahrbuch, E23, 165-206.

Shaked Y., Avigad, D., Garfunkel, Z., 2000. Alpine high-pressure metamorphism at the Almyropotamos window (southern Evia, Greece). Geol. Mag. 137 (4), 367-380. 